\title{
Summary of the Research on the Development Model of Military-Civil Integration Based on Industry-University-Research Integration
}

\author{
Hongfei Guo \\ Institute of Physical Internet, Jinan University, Zhuhai, China \\ E-mail: ghf-2005@163.com
}

Chunyu Xu (Corresponding author)

School of electrical information, Jinan University, Zhuhai, China

E-mail: 1120365796@qq.com

Zhixuan Lin

International Business School, Jinan University, Zhuhai, China

\section{Yuqiao Liang}

International Business School, Jinan University, Zhuhai, China

\begin{abstract}
Ru Zhang
Finance Department of International Business School, Jinan University, Zhuhai, China E-mail: zhangru@stu2016.jnu.edu.cn
\end{abstract}

\author{
Zhihui He \\ Zhuhai Hengqin Building \& Construction Quality Inspection Centre Co., Ltd \\ Zhuhai, 519031, China
}


Yitao Lun

School of electrical information, Jinan University, Zhuhai, China

Qiufan Chen

School of electrical information, Jinan University, Zhuhai, China

Guoquan Huang

Institute of Physical Internet, Jinan University, Zhuhai, China

Received: September 30, 2018 Accepted: November 13, 2018 Published: November 16, 2018

doi: 10.5296/jsss.v6i1.13923

URL: https://doi.org/10.5296/jsss.v6i1.13923

\begin{abstract}
As a hot topic in the current academic and national application research, the cooperation of Industry- University-Research and Military-Civilian Integration play an extremely important role in the policy of wealth the country and strengthening the military. This paper summarizes the development history of Military-Civilian Integration based on "Industry-University-Research", Military-Civilian Integration and "Industry-University-Research", and sums up the research status of the Military-Civilian Integration development model based on "Industry-University-Research" in the academic world. Basing on it, this paper carries out literature review to provide further guidance for the in-depth study of Military-Civilian Integration of "Industry-University-Research”.
\end{abstract}

Keywords: Industry-University-Research, Military-Civilian Integration, Literature review

\title{
1. Introduction
}

Industry-University-Research cooperation and Military-Civilian Integration are hot topics in applied research at current academic and national levels. In October 2017, the 19th CPC National Congress of China report on the "Military-Civilian Integration", from the "Military-Civilian Integration Development Strategy", to the "Military-Civilian Integration Depth Development Pattern", focusing on the progressive mode of strengthening military integration in rich countries strategic position in strengthening armed forces; This paper clarifies new goals and tasks of civil-military integration development in new era and constructs a complete system from ideology to strategy to task. At the same time, the "National Program for Medium-to-Long-Term Scientific and Technological Development" clearly states that the cooperation between industry, academia and research is not only the basic principles and requirements for the construction of Military-Civilian Integration 
technology innovation system, but also an important way to realize the construction of Military-Civilian Integration technology innovation system. At the end of 2017, the National Security Strategy of the United States of America stated: "Departments and agencies must work with industry to experiment, prototype, and rapidly field new capabilities that can be easily upgraded as new technologies come online." In the space field: "As the U.S. Government partners with U.S. commercial space capabilities to improve the resiliency of our space architecture, we will also consider extending national security protections to our private sector partners as needed." As a country defeated by the Second World War, Japan was affected by the post-war agreement. Japanese national defense construction was dominated by the civilian sector. It encouraged development of dual-use technologies through free transfer of military technology, financial subsidies and tax incentives. In addition, Russia, South Korea, Germany and other countries have introduced a series of policies to encourage universities and governments to cooperate and achieve technological innovation. Therefore, how to explore and construct a "Industry-University-Integration" model that highlights the "dual-use strategy" as a demand feature to realize the deep development of Military-Civilian Integration has become a strategic issue for important research in today's academic circles.

\section{Research Status of "Industry-University-Research" in Military-Civilian Integration}

\subsection{Research Status of "Industry- University-Research"}

Industry-University-Research refers to cooperation between enterprises, research institutes and higher education universities, which usually refers to the cooperation between enterprises as technology demanders and research institutes or higher education universities as suppliers. The essence is to promote the effective combination of various production factors required by technological innovation. Since Industry-University-Research cooperation has effectively promoted economic development, it has become an important issue in innovation policies of many countries, and it is even promoted as the national innovation strategy to research.

Among them, as for the cooperation model of Industry-University-Research, scholars Etzkowitz and Leydesdorff jointly proposed the "triple spiral" nonlinear innovation model of government-industry-education for the first time (2000), reshaping the "Government-Industry-University" tripartite relationship and role, gradually formed the six major cooperation model of Industry-University-Research in the United States, including the university science park model, business incubator model, cooperative research center model, contract cooperation research model, consulting agreement model, and technology share cooperation model. The scholar Jingzhen Zhou (2004), by comparing different modes of cooperation, adopting historical research, comparative analysis, logical reasoning and other methods, proposed a more efficient Chinese-style cooperation model of Industry-University-Research for Chinese specific national conditions, namely Government Directives Model, Government-Driven Model, Enterprise-Led Model, University-led model, Research Institute-Led Model, Co-Building Mode and Virtual Model.

As for the innovation aspect of Industry-University-Research cooperation, the scholar Etzkowitz (2008) proposed that in addition to education and research, Industry-University-Research cooperation is the new mission of the university. In the 
knowledge-based society, the three-way interactive cooperation among "University-Industry-Government" is a necessary condition for constructing national innovation system and enhancing innovation capabilities. Xia Gao (2014) believes that collaborative innovation of Industry-University-Research is a new formulation, as well as a new development of the national innovation model - the "three-helix" theory, which is also a new development of the cooperation theory of Industry-University-Research with Chinese characteristics. Based on the "three-helix" theory, the research on collaborative innovation of Chinese Industry-University-Research is gradually evolving from the increasingly mature research on cooperation between Industry-University-Research with Chinese characteristics, which is in the ascendant. At the same time, Xiaoxia Lan(2014) believes that strengthening the collaborative innovation of Industry-University-Research and enhancing national innovation capability is a major development trend of world science and technology innovation. The collaborative innovation of Industry-University-Research of America has multiple modes of action. Each entity collaborates in a specific organizational structure and activity mode. The applicable objects, cooperation content, methods and effects of different models are diverse. This paper studies the main modes of collaborative innovation in the United States from the aspects of formation methods and scientific research results transformation, so as to provide reference for the optimization of Chinese collaborative innovation model. Haiyun $\mathrm{Xu}$ et al. (2018) analyzed the conditions and dynamics in cooperation process of Industry-University-Research based on the innovation chain theory, and combined the bibliometrics and econometric analysis to capture the core network and institutional competitiveness of the existing collaborative network in the innovation chain. At the same time, it also considers the law of scientific cooperation and economic factors, so as to propose a new method which can effectively identify potential industry-education research partners.

\subsection{Research Status of Military-Civilian Integration}

Military-Civilian Integration is to deeply integrate the national defense and military modernization into the economic and social development system, comprehensively promote Military-Civilian Integration in various fields such as economy, science and technology, education and talents, combining national defense and military modernization with economic and social development at a wider range, higher level and deeper extent, so as to provide abundant resources and sustainable development momentum for the realization of national defense and military modernization.

In the theory of Military-Civilian Integration, Ping Yang (2012) believes that with the in-depth development of Military-Civilian Integration, the military standardization system is facing profound changes, which will have has far-reaching impact on the quality assurance of the military, the level of technological progress, the acquisition of market mechanisms and the national defense industry. The development has far-reaching implications. Hui Xu (2014) retrospectively analyzes the process of Chinese Military-Civilian Integration evolution and the connotation of the deep development from the perspective of historical evolution, and studies and summarizes the main contradictions existing at present, as well as proposing suggestions for further development from the perspective of national strategic deployment. 
Combining national defense and military modernization with economic and social development at a wider range, higher level and deeper extent, so as to provide abundant resources and sustainable development momentum for the realization of national defense and military modernization. Mantao Guo (2015) pointed out that the Third Plenary Session of the 18th CPC Central Committee incorporated the in-depth development of Military-Civilian Integration into the overall layout of the party and the national comprehensive deepening reform. Facing the new situation and new requirements of national defense and military construction, only by in-depth research and grasping the characteristics of Military-Civilian Integration, establishing the deep integration concept, constructing the deep integration model, and perfecting the deep integration mechanism can we continuously open new situation of reform and strengthening the military. Renhuai $\mathrm{Du}$ (2016) believes that the development of Military-Civilian Integration is the move to rejuvenate the country and strengthen the military. Yujuan Zou et al. (2017) believe that the deep development of Military-Civilian Integration is the need of the times and the trend. Encourage private capital and enterprises to enter certain military fields, which will not only continuously improve the armaments and combat effectiveness of the military, but also promote the rapid development of the local economy. At present, the overall benefits and huge potential of Military-Civilian Integration in China need to be tapped and further developed. It is recommended to strengthen the top-level design and coordination mechanism to promote the reform and transformation of military enterprises; break the barriers that hinder private enterprises, improve relevant laws and regulations and policy guarantees; set up platform for Military-Civilian Integration and promote private capital to enter the military industry. Zibin Liu et al.(2017) believe that the development of Military-Civilian Integration into national strategy is to achieve the unity of wealth the country and strengthen military forces, while promote the deep integration of economic construction and national defense construction. On the basis of analyzing the basic theories and contradictions of Military-Civilian Integration development, they try to learn from the experience and practice of major countries in the world, propose countermeasures for development of Military-Civilian Integration that are suitable for Chinese condition, as well as exploring the mode and path for development of Military-Civilian Integration.

In the application of Military-Civilian Integration, B Fenistein (2004) pointed out that the establishment of a formal dental team in the French Armed Forces in the daily care, vocational training or research activities in synergy with the civilian world helps to maintain the military relationship. Cristiano (2013) proposed a proposal for government innovation and intelligence models, arguing that government actions would help increase the information avalanche in the current social network era without knowledge management, knowledge management, and organizational intelligence-OI guidance. Zhao et al. (2013) believe that the continuous development of Military-Civilian Integration equipment maintenance support has accompanied the creation and development of war and military equipment. It has experienced three important historical periods, including the original Military-Civilian Integration, military-civilian separation, and military-civilian reintegration. Its development process is directly subject to various factors such as target, economy, technology and so on. Under the current situation, it is necessary to steadily advance the reform of Military-Civilian Integration equipment maintenance support on the basis of the actual development of military 
equipment and science. Travis M. Polk et al. (2015) can successfully adjust civilian life support courses to meet military training needs by civilizing ATLS, a military trauma technology. George T. Schmidt (2015) summarizes latest advances in navigation sensor technology used in both civil and military applications, including GPS, inertia and other navigation aids to solve these issues. Yi Liu (2015) starts with the basic theory of technology transfer, reviews the research results of the existing military-civilian dual-use technology, and discusses the significance of dual-use technology integration in the context of the current global industrial transformation acceleration and the accelerated implementation of innovation-driven development strategies in China, as well as proposing to accelerate the military-civilian dual-use technology integration in emerging industries. Yong Zhan et al. (2016) base on the theoretical model of capital market, Military-Civilian Integration and industrial structure optimization and upgrading, using the Chinese provincial panel data and the Two-Stage system GMM estimation method between 2007 to 2014, and carry out empirical test on the proposed hypothesis that "Military-Civilian Integration is a national strategy to realize the Chinese dream and powerful military dream, which is of great significance to promote the development of national defense science and technology industry and the upgrading of industrial structure." Zhaofeng Huang et al. (2017) applied the division of labor theory to study the mechanism of Military-Civilian Integration development to promote economic construction and national defense construction. On the basis of Military-Civilian Integration and optimization of resource allocation, it further revealed the organizational structure change and organizational performance of Military-Civilian Integration, meanwhile expanded and deepened the understanding of Military-Civilian Integration

\subsection{Research Status of Military-Civil Integration Based on "Integration of Industry-University-Research"}

Under the new situation of complex world politics and economy, how to coordinate the high integration of economic construction and national defense construction under the constraints of limited resources has become the only way for the Military-Civil Integrations to deepen development, and is also a major topic that the countries of the world are actively exploring. In view of some unsolvable technical problems in the process of Military-Civil Integration, choosing to cooperate with creative universities and realize technological innovation has become a trend of modern Military-Civil Integration.

In theoretical aspect, Xiaohui Shi et al. (2011) embarks from the essential characteristics of cooperation between the different natures of the Industry-University-Research cooperation, aiming at the problems and reasons of the actual objective analysis of the construction of Chinese Military-Civil Integration technology innovation system, focus at the characteristics and laws of the construction of Military-Civil Integration technology innovation system. This paper proposes the policy and measures of perfecting and innovating China's Military-Civil Integration technology innovation system based on the cooperative mechanism of Industry-University-Research and provides theoretical basis for improving Chinese Military-Civil Integration innovation system. Bingxing Zeng et al. (2011) believed that the integrated development of Industry-University-Research and the construction of Military-Civil Integration seem to be different events in two fields or two aspects, but in fact 
they are inextricably linked. They comprehensively analyzed the background and development process of the Military-Civil Integration construction thoughts, briefly reviewed the development of China's domestic Industry-University-Research integration, and expounded several thoughts of the author on the problems in the current combination of theoretical research and practice: 1) Establishing a sense of urgency and overall situation; (2) Taking the development of independent innovation as a strategic point for the development of integration of Industry-University-Research, and Military-Civil Integration; (3) Integrating classification and appropriate integration as a breakthrough in the development of integration of Industry-University-Research and Military-Civil Integration (4) Take project planning, organization and implementation as the focus of integration of Industry-University-Research and Military-Civil Integration. Xiaomei $\operatorname{SUN}^{[}$(2014) constructed the university science and technology innovation platform based on the perspective of Industry-University-Research cooperation, and proposed that university is the technical support and innovation source of enterprise innovation, and the technical requirements of enterprise are the driving force of university technology innovation. Cooperation between universities and enterprises can integrate high-quality resources and improve scientific and technological innovation ability.

In terms of technological innovation, Linna WANG et al.(2011) analyzed the necessity and urgency of SMEs' implementation of Industry-University-Research cooperation innovation, described the definition and characteristics of virtual teams, demonstrated the construction elements of SMEs Industry-University-Research virtual teams, and proposed corresponding countermeasures. From the construction of government support, system guidance and enterprise incentive mechanism to ensure the team construction and normal, efficient operation. Xiaohui Dong (2013) proposed a conceptual framework and theoretical model of the "four in one" collaborative innovation of Military-Civil Integration industrial clusters by combing the theoretical sources and research literatures. Xia Gao (2014) reviewed China's information and communication technology sector and its impact on China's national and regional innovation systems through research, and proposed to encourage more universities and research institutions to participate in "Industry-University-Research" cooperation to help enterprises improve their innovation capacity. Chunhua FENG et al. (2015) objectively summarized the successful experience of the United States in long-term cooperation, and summarized the experience of promoting the construction of technological innovation system based on the cooperation between Industry-University-Research. Haiyan He (2015) thinks that Military-Civil Integration and cooperation between Industry-University-Research can be regarded as an industrial chain which determines the property right structure of the whole system firstly, then carries out scientific research and production, and finally put into market use. It is divided into three strategic layers. The first layer is the front-end investment and financing strategy, the second is the medium-end innovation capacity improvement strategy and the construction strategy of scientific research and production system, and the third layer is the global development strategy of dual-use market. Yan $\mathrm{Xu}$ (2015) found that the cooperation of production, teaching and research in national defense research in Chinese universities is highly in line with the national "innovation-driven development strategy" and "deep development strategy of Military-Civil Integration ", which is the inevitable trend and direction of the development of national defense science and technology in universities. The 
cooperation between universities and military enterprises through the establishment of cooperation committees, joint funds and joint research platforms is conducive to promoting mutual complementarity of advantages, resource sharing and win-win situation. Yaling Wang (2017) pointed out that the construction of an innovative country must have a strong high-end equipment manufacturing industry. The high-end equipment manufacturing industry, which provides production technology and equipment for the national economy and national defense construction, is a key area of collaborative innovation between the military and the people in China. The western region is a concentrated area of national defense science and technology resources in China. The system and mechanism should be designed from the three dimensions of military and civilian collaborative innovation, Industry-University-Research collaborative innovation and industrial life cycle to solve the problem of weak innovation capacity of high-end equipment manufacturing industry. Zhen-Zhou Tu et al. (2017) combined innovation theory with multi-level extension evaluation method to establish the IUR-SI system synergy evaluation index system and evaluation model based on knowledge creation. Ming Luo (2017) put forward the concept of CDIO-based cooperative construction of Industry-University-Research performance evaluation research to promote the construction of practice base, and analyzed it.

\section{Conclusion}

From the practical experience, we can see that the system of "Industry-University-Research" and the Military-Civil Integration is beneficial to the economic development and social progress of all countries. For example, the United States, through the cooperation between military enterprises and universities, makes the degree of Military-Civil Integration of the national defense construction system more in-depth, not only improves the national competitiveness but also strengthens the economic and military soft power. According to the American Astronautical Industry Association's report, The Economic Impact Analysis of Aerospace and Defense, the U.S. aerospace and defense industries created $\$ 300$ billion in economic value in 2015, accounting for $1.8 \%$ of nominal GDP.

For China, since the Third Plenary Session of the Eleventh Central Committee, a coherent policy of Military-Civil Integration has been implemented to encourage two-way technology transfer between the military and civilian sectors. In the 2016 Report on the Development of China's Military-Civil Integration, it is pointed out that since the reform and opening up, the military industrial departments have gradually formed a diversified industrial development pattern in which military products are the main products and civilian products are the supplement. The proportion of civilian products output value of the military industrial departments has basically stabilized from $70 \%$ to $80 \%$. According to statistics, the revenue of civilian products industry in the military industry in 2014 increased by about 1.6 times compared with six years ago, and achieved remarkable economic and social benefits.

The mode of cooperation between military enterprises and universities in every country and region is not single, but diversified, including cooperative centers, research institutes, science and technology parks. By learning these advanced modes of cooperation and combining the idea of Military-Civil Integration, we can change the narrow scope, monotonous content, low level and single form of cooperation in the Industry-University-Research cooperation, thus enriching the flow of resources, so that "Industry-University-Research" can play a better role 
in the Military-Civil Integration. In the Industry-University-Research model of Military-Civil cooperation, strong technological innovation capacity can drive and strengthen the desire of all parties to cooperate, while the open and effective industrial policies can provide a sound policy environment for cooperative innovation and development. Besides, in addition to some existing models, we can also establish corresponding models with our own characteristics according to the specific national conditions, historical background and regional environment of each country. Based on the historical process of the cooperative development between Industry-University-Research and the military government, as well as the existence mode, status, mutual relations and integration degree of various subjects, this paper divides and discusses the in-depth development mode of Military-Civil Integration based on the "integration of Industry-University-Research" from the aspects of structure and function.

\section{Acknowledgement}

The research and publication was supported by funds below:

The Fundamental Research Funds for the Central Universities, NO. 21618412;

Inner Mongolia Autonomous Region Science and Technology Innovation Guide Award Fund Project, NO. 103-413193.

Scientific Research Project of Henan Colleges and Universities in 2019, based on the research on military science and technology innovation mechanism of colleges and universities from the perspective of civil-military integration, NO. 19A630037.

Fund of Research on Enterprise Management Innovation Mode System, NO. 44860070;

Fund of Research on the Enterprise Management Mode and Countermeasures Based on the Production, Study and Research, NO. 44860071.

\section{References}

Chunhua, F., \& Baojun, S. (2015) The Experience and Enlightenment of American University Research Cooperation Innovation. International Business and Management, 11(1).

Cristiano Trindade De Angelis.( 2013). Uma proposta de um modelo de inovação e inteligência governamental. RAI Revista de Administração e Inovação, 10(3).

Davis, M. (2014). The triple helix: university-industry-government innovation in action henry etzkowitz. Journal of Chemical Physics, 79(1), 265-272.

Dong, X. H. (2013). Research Review and Theoretical Framework of Collaborative Innovation in Civil-Military Integration Industrial Clusters. Journal of Systems Science, 4, 60-64.

Du, R. H. (2016). Fully Promoting the Deep Integration of Military and Civilian Affairs: Studying General Secretary Xi Jinping's Important Thought on Deep Integration of Military and Civilian Affairs. Observation and Thinking, 2, 17-24.

Gao, X. (2014). A review of the research context and current situation of collaborative 
innovation between Industry-University-Research Institute in China. Scientific Management Research, 5, 9-11. https://doi.org/10.19445/j.cnki.15-1103/g3.2014.05.003

Gao, X., Guo, X., \& Guan, J. (2014). An analysis of the patenting activities and collaboration among industry-university-research institutes in the chinese ict sector. Scientometrics, 98(1), 247-263. https://doi.org/10.1007/s11192-013-1048-y

Guo, M. T. (2015). Promoting the in-depth development of Military-Civil Integration. Journal of Xi'an Institute of Political Science, 28(6), 62-64. https://doi.org/10.3969/j.issn.100 8-5815.2015.06.013

He, H. Y. (2015). Reflections on cooperation between military and civilian production, education and research. China Science and Technology Industry, 9, 12-13.

Henry, E., \& Loet, L. (2000). The dynamics of innovation: from national systems and "mode 2 " to a triple helix of university-industry-government relations. Research Policy, 29(2), 109-123. https://doi.org/10.1016/S0048-7333(99)00055-4

Huang, C. F., Ju, X. S., Ji, J. Q., \& Meng, B. B. (2017). ow can Military-Civil Integration enrich the country and strengthen the army? ---Military-Civil Integration, division of labor evolution and increasing returns. Economic Research, 8.

Lan, X. X. (2014). Major Models, Characteristics and Enlightenment of Collaborative Innovation between Industry-University-Research in the United States. China Higher Education Research, 4.

Liu, Y. (2015). Research on the Integration of Military and Civilian Dual-use Technologies in Emerging Industries and Suggestions for Guangdong. Science and Technology Management Research, 16, 136-139. https://doi.org/10.3969/j.issn.1000-7695.2015.16.025.

Liu, Z. B, Yu, B., \& Liu, J. (2017). Models and Paths for Implementing the Development Strategy of Civil-Military Integration. Macroeconomic Management, 11, 29-33.

Ming, L., Lei, S., \& Ming-Jing, X. (2017). Research on the construction performance assessment of Industry-University-Research cooperation in collaborative innovation to promote the practice base construction based on CDIO idea. Journal of Intelligent \& Fuzzy Systems, 33(6).

Schmidt, G. T. (2015). Navigation sensors and systems in gnss degraded and denied environments. Chinese Journal of Aeronautics, 28(1), 1-10. https://doi.org/10.1016/j.cja. 2014.12.001

Shi, X. H., \& Xu, G. (2011). Research on the Technological Innovation System of Military-Civil Integration Industry Based on Industry-University-Research Cooperation. Chinese Academy of Engineering. China Engineering Science and Technology Forum No.123-Proceedings of National Defense Science, Technology and Industry Science Development Forum.

Sun, X. (2014). Constructing university scientific and technological innovation platform based on the view of industry-university-research cooperation. Higher Education of Social 
Science.

Travis, M., Stockinger, Z. T., Martin, M. J., \& Gross (2015). Successful integration of military tactical requirements into a civilian training paradigm: advanced trauma life support - operational emphasis (atls-oe). Journal of the American College of Surgeons, 221(4), e76-e76. https://doi.org/10.1016/j.jamcollsurg.2015.08.098

Tu, Z. Z., Gu, X., \& Ye, Y. J. (2017). Synergy evaluation of industry-university-research institute synergetic innovation system based on knowledge creation. Journal of Discrete Mathematical Sciences and Cryptography, 20(1), 16.

Wang, L., \& Zhu, K. (2011). Research on the construction of technology innovation virtual team in smes: based on the perspective of industry-university-research cooperative innovation. Management Science \& Engineering, 5(2).

Wang, Y. L. (2017). Research on the Collaborative Innovation of Military, Civilian, University and Research Institute in the Western High-end Equipment Manufacturing Industry: A Case Study of Shaanxi Province. Journal of Xi'an Jiaotong University (Social Science Edition), 37(2), 38-43.

$\mathrm{Xu}, \mathrm{H}$. (2014). Major Issues and Suggestions on the Deep Development of Civil-Military Integration in China. Introduction to Economic Research, 30, 277-278. https://doi.org/10.396 9/j.issn.1673-291X.2014.30.115

Xu, H., Wang, C., Dong, K., Luo, R., Yue, Z., \& Pang, H. (2018). A study of methods to identify industry-university-research institution cooperation partners based on innovation chain theory. Journal of Data and Information Science, 3(2). https://doi.org/10.24 78/jdis-2018-0008

$\mathrm{Xu}$, Y. (2015). Research on Industry-University-Research Cooperation in National DefenseRresearch in Universities. Science and Technology in Chinese Universities, 4, 33-35.

Yang, P., \& Xiao-He, C. (2013). Research on military standardization reform and defense industry development based on a view of military-civilian integration. International Conference on Management Science \& Engineering. https://doi.org/10.1109/ICMSE.2012. 6414306.

Zeng, B. X., Zeng, L. C., \& Wang, B. (2011). Some thoughts on the integration of Industry-University-Research and the Military-Civil Integration construction. Science and Technology Entrepreneurship Monthly, 24(10), 6-8. https://doi.org/10.3969/j.issn.167 2-2272.2011.10.003

Zhan, Y., \& Zhao, C. K. (2016). Capital market development, Military-Civil Integration and industrial structure optimization and upgrading. Nankai Economic Research, 5, 36-54.

Zhao, M., Du, H., Zhang, H., \& Feng, L. (2013). The historical evolution and inspiration of military-civilian integration of equipment maintenance support relation. International Conference on Quality. IEEE. https://doi.org/10.1109/QR2MSE.2013.6625808 
Zhou, J. Z. (2004). Discussion on the mode of innovation of China's academic research cooperation. Nanjing University of Technology.

Zou, Y. J., \& Wang, L. (2017). Further accelerate the in-depth development of Military-Civil integration research. China's National Conditions and Strength, 8, 62-65. https://doi.org/10. 13561/j.cnki.zggqgl.2017.08.019

\section{Copyright Disclaimer}

Copyright for this article is retained by the author(s), with first publication rights granted to the journal.

This is an open-access article distributed under the terms and conditions of the Creative Commons Attribution license (http://creativecommons.org/licenses/by/3.0/). 